\title{
Animal production, economic results and lessons from nitrogen fertiliser use on dry hill country
}

\author{
A.G. GILLINGHAM ${ }^{1}$, M.H. GRAY ${ }^{2}$ and J.D. MORTON ${ }^{3}$ \\ ${ }^{1}$ AgResearch, Grasslands Research Centre, PB 11008, Palmerston North \\ ${ }^{2}$ AgResearch, Poukawa Research Centre, P.O. Box 8144, Hastings \\ ${ }^{3}$ AgResearch, Invermay Agricultural Research Centre, PB 50034, Mosgiel \\ allan.gillingham@agresearch.co.nz
}

\begin{abstract}
Over a 7 year period, two trials were conducted on dry, steep hill country near Waipawa, central Hawkes Bay to examine the effects of combinations of nitrogen $(\mathrm{N})$ and phosphorus (P) fertilisers on sheep and cattle production. Four farmlets were established and balanced so that each contained similar proportions of predominantly north and south facing aspects, and easy $\left(0-20^{\circ}\right)$ and steep $\left(>20^{\circ}\right)$ slopes. For Trial 1 from 1995 to 1999 , the 'Low P' farmlets had a soil Olsen P test of $9 \mu \mathrm{g} / \mathrm{ml}$, and the 'High P' farmlets had a test of $28 \mu \mathrm{g} / \mathrm{ml}$ (paddock averages). One each of the Low $\mathrm{P}$ and of the High $\mathrm{P}$ farmlets received $\mathrm{N}$ overall in early to mid winter at $30 \mathrm{~kg} / \mathrm{ha}$ applied in urea fertiliser. The trial was stocked with an initial ratio of about 65:35 sheep (5 year old Romneys) to cattle (18 month old Friesian/Angus). The stocking rate for each farmlet was individually set to fully utilise the expected pasture growth on each farmlet during winter. Standard costs and returns were used for the economic analysis in all years.
\end{abstract}

High soil $\mathrm{P}$ status and use of $\mathrm{N}$ fertiliser were not economically worthwhile unless ewe numbers were maximised and spring pasture was fully utilised. This was achieved by having farmlets fully stocked with ewes during winter with cattle introduced in early spring to control additional pasture growth. This strategy was particularly successful in a drought year (1998) when N fertiliser allowed a significantly higher ewe stocking rate during winter. The farmlets receiving $\mathrm{N}$ fertiliser averaged $\$ 148 /$ ha economic net margin compared with $\$ 117 /$ ha from those without $\mathrm{N}$ fertiliser.

In Trial 2, differential application of $\mathrm{P}$ (to easy slopes only) and $\mathrm{N}$ fertilisers (to steep slopes only) occurred in two of the farmlets. This provided higher economic returns than in Trial 1. The plus- $\mathrm{N}$ farmlets averaged \$234/ha compared with $\$ 184 /$ ha for those without N fertiliser. A major advantage of the differential fertiliser application approach is that the appropriate $\mathrm{N}$ or $\mathrm{P}$ fertiliser is applied only to areas that will provide the best responses from that type of fertiliser

The success of intensified fertiliser use and stocking of dry hill country is dependent on maximising pasture use while reliable soil moisture and pasture growth conditions prevail i.e. early winter- early spring.
Outside this period management options must be flexible enough to cope with drying conditions at any time.

Keywords: animal production, economic net margin, hill pastures, nitrogen, phosphorus

\section{Introduction}

The subject of nitrogen $(\mathrm{N})$ fertiliser use on hill country for increased productivity is currently of considerable interest throughout the sheep and beef industry. In summer moist hill country Lambert (1986) measured sizable pasture growth responses to both phosphorus (P) and N fertilisers and Ball \& Field (1982) also concluded that reliable and large $\mathrm{N}$ fertiliser responses are generally obtained from hill pastures in moist environments. More recently Lambert et al. (2003) showed that rates of $\mathrm{N}$ fertiliser up to $400 \mathrm{~kg} / \mathrm{ha}$ could produce responses of near $20 \mathrm{~kg} \mathrm{DM} / \mathrm{kg} \mathrm{N}$ fertiliser applied.

In summer dry hill country the role of $\mathrm{N}$ fertiliser in enhancing pasture production has been evaluated for a number of years and reported at previous NZGA Conferences (Gillingham et al. 1998; Gillingham et al. 1999; Gillingham et al. 2003a, 2003b). This work at the Waipawa Research Area in central Hawkes Bay has shown that the application of $\mathrm{P}$ fertiliser to land that has little legume content in the pasture results in only small pasture dry matter (DM) production responses, and the strategic use of $\mathrm{N}$ fertiliser in winter, when soil moisture levels are adequate for pasture growth, will achieve higher pasture production on such areas. Conversely the continued application of $\mathrm{P}$ fertiliser to associated land with pastures of higher and more persistent legume content was the best approach, although $\mathrm{N}$ also produced good DM production responses in spring. These results were obtained within the frame work of farmlet trials established to provide realistic scale information on animal production from contrasting fertiliser regimes, and to use that information to derive comparative economic analysis of farmlet profitability.

Two trials with differing fertiliser application regimes were conducted over the period from 1995 to 2003. This paper presents results of the animal management and production throughout that period and discusses the 
economics of $\mathrm{P}$ and $\mathrm{N}$ fertiliser use on summer dry hill country.

\section{Methods \\ Site}

The Waipawa trial site, soils and location were described by Gillingham et al. (1998).

Four farmlets were established with each comprised of 12 , one-hectare paddocks. The 48 paddocks in the trial covered steep, summer-dry hill country and farmlets were balanced so that each contained similar proportions of predominantly north and south facing aspects, and easy $\left(0-20^{\circ}\right)$ and steep $\left(>20^{\circ}\right)$ slopes.

Annual rainfall during the study period ranged from 883 to $996 \mathrm{~mm}$ from 1995 to 1999 with a drought in 1998 when annual rainfall was $559 \mathrm{~mm}$. From 2000 to 2003 the rainfall ranged from 857 to $879 \mathrm{~m}$.

For Trial 1 from 1995 to 1999, two of the farmlets had an Olsen P test of $9 \mu \mathrm{g} / \mathrm{ml}$ (Low P), and two had a test of $28 \mu \mathrm{g} / \mathrm{ml}$ (High P) as paddock averages. Soil tests were in September annually and these results, together with production data, were used to estimate the annual $\mathrm{P}$ fertiliser application requirement to maintain these levels.

One each of the Low P and of the High P farmlets received $30 \mathrm{~kg} \mathrm{~N} / \mathrm{ha}$ as urea fertiliser in early to midwinter.

\section{Management and measurements}

The trial was stocked with an initial ratio of about 65:35 sheep ( 5 year old Romneys) to cattle (18 month old Friesian/Angus). Each farmlet was self contained from 1 May, or earlier, if autumn rainfall was sufficient to establish target pasture cover levels of $1500 \mathrm{~kg} \mathrm{DM} / \mathrm{ha}$, until approximately December, depending on spring rainfall and associated pasture availability. Animals were rotationally grazed within each farmlet.

The stocking rate for each farmlet was individually set to fully utilise the expected pasture growth on each farmlet through until lambing when active spring growth usually commenced. Factors used in the calculation of the stocking rate for each farmlet were the pasture cover when stock were introduced, expected pasture growth rate during winter, ewe requirements during winter and residual pasture cover at the start of lambing.

Ewes were stocked at rates estimated to achieve similar levels of pasture control, and similar ewe body weights, on each farmlet at any one time. This was managed largely by having a flexible cattle grazing policy. Ewe stocking rates and the cattle ratio varied from year to year as a result of differences in pasture growth conditions. Differences in animal productivity between farmlets were therefore due to a combination of animal numbers and animal productivity.

Lambs were weaned in early-December and all sold as prime or stores. Fifty per cent of the ewes were culled and sold at this time. Cattle were removed from the trial when either there was no pasture surplus to ewe and lamb requirements in mid spring (ie. when pasture mass was near $1200 \mathrm{~kg} \mathrm{DM} / \mathrm{ha}$ ), or in early-December when lambs were weaned.

Economic analysis used 1997 costs and returns for all years so that climatic and management changes could be more easily compared. Capital P fertiliser applied at the start of the trial to raise the soil P status in the High P farmlets was discounted over a 10 year period ( $\$ 20 / \mathrm{ha} /$ yr). Results show both the discounted net margin as well as the long term (after 10 years) net margins for the High $P$ farmlets. Farmlets with stock numbers greater than those carried in the Low P farmlet were regarded as capital investment and discounted accordingly. The average maintenance $P$ fertiliser applied over the 199599 period $(10 \mathrm{~kg} / \mathrm{ha}$ for Low $\mathrm{P}$ farmlets; $16 \mathrm{~kg} \mathrm{P} / \mathrm{ha}$ for High $\mathrm{P}$ farmlets) was used in the economic analysis for individual years. Sulphur application averaged $21 \mathrm{~kg} / \mathrm{ha}$ annually over the whole trial.

In Trial 2 from 2000 to 2003, the fertiliser policy was modified with the aim of obtaining the best efficiency from each fertiliser type. Based on Trial 1, results fertiliser $\mathrm{N}$ was applied at $50 \mathrm{~kg} / \mathrm{ha}$ to only steep slopes in the Low $\mathrm{P}+\mathrm{N}$ and High $\mathrm{P}+\mathrm{N}$ farmlets, and the soil $\mathrm{P}$ status on easy slopes in the previously Low $\mathrm{P}$ and Low $\mathrm{P}+\mathrm{N}$ farmlets was raised to a medium (Olsen $\mathrm{P}=15 \mu \mathrm{g} / \mathrm{ml}$ ) level (Moderate $\mathrm{P}$ and Moderate $\mathrm{P}+\mathrm{N}$ farmlets respectively). The soil $\mathrm{P}$ status on easy slopes in the High P farmlet, and on both easy and steep slopes in the High $\mathrm{P}+\mathrm{N}$ farmlet, were as in Trial 1. The maintenance $\mathrm{P}$ and $\mathrm{S}$ fertiliser rates in Trial 1 were continued in Trial 2. The economic analysis used the same costs as in Trial 1.

\section{Results}

\section{Trial 1}

Within each year the trial protocol to maintain ewes on each farmlet at the same body weight at any one time was generally achieved (results not shown) and so wool production per ewe in each farmlet was also similar in each year. For the period May to December annually this averaged about $2 \mathrm{~kg} /$ ewe.

There were three phases of Trial 1 that emerged in the results. The first period was from 1995-1997. Animal production results during this period showed a response to $\mathrm{P}$ fertiliser, with $\mathrm{N}$ fertiliser providing an increase at each P level (Table 1). However the average economic net margin did not reflect animal production levels and was highest on the Low $\mathrm{P}$, lower in the Low $\mathrm{P}+\mathrm{N}$ and High $\mathrm{P}$ farmlets, and lowest in the High $\mathrm{P}+\mathrm{N}$ farmlet. The long term net margin, as would apply on a farm that had applied capital $\mathrm{P}$ fertiliser more than 10 years previously, was highest on the High P farmlet, and was 
Table 1 Mean sheep and cattle numbers, lamb and cattle production (kg live weight/ha) and economic net margin per farmlet (1995-1997). Long term economic net margins (\$/ha) for High $P$ farmlets shown in brackets.

\begin{tabular}{lccccccc}
\hline & $\begin{array}{c}\text { Ewe } \\
\text { numbers }\end{array}$ & $\begin{array}{c}\text { Cattle } \\
\text { numbers }\end{array}$ & $\begin{array}{c}\text { Lamb } \\
\text { wt }\end{array}$ & $\begin{array}{c}\text { Cattle } \\
\text { wt gain }\end{array}$ & $\begin{array}{c}\text { Total } \\
\text { live wt }\end{array}$ & $\begin{array}{c}\text { Relative } \\
\text { live wt(\%) }\end{array}$ & $\begin{array}{c}\text { Net } \\
\text { margin }\end{array}$ \\
\hline Low P & 52 & 5 & 114 & 54 & 168 & 100 & 149 \\
Low P+N & 55 & 6 & 154 & 67 & 221 & 132 & 136 \\
High P & 60 & 6 & 142 & 59 & 201 & 120 & 136 \\
High P+N & 63 & 7 & 156 & 57 & 213 & 127 & $(156)$ \\
& & & & & & & $(126)$ \\
\hline
\end{tabular}

Table 2 Mean sheep and cattle numbers, lamb and cattle production (kg live weight/ha) and economic net margin (\$/ha) per farmlet (1998). Long term net margins for High $P$ farmlets shown in brackets.

\begin{tabular}{lccccccc}
\hline & $\begin{array}{c}\text { Ewe } \\
\text { numbers }\end{array}$ & $\begin{array}{c}\text { Cattle } \\
\text { numbers }\end{array}$ & $\begin{array}{c}\text { Lamb } \\
\text { wt }\end{array}$ & $\begin{array}{c}\text { Cattle } \\
\text { wt gain }\end{array}$ & $\begin{array}{c}\text { Total } \\
\text { live wt }\end{array}$ & $\begin{array}{c}\text { Relative } \\
\text { live wt(\%) }\end{array}$ & $\begin{array}{c}\text { Net } \\
\text { margin }\end{array}$ \\
\hline Low P & 29 & 5 & 99 & 25 & 124 & 100 & 126 \\
Low P+N & 45 & 9 & 138 & 37 & 175 & 141 & 159 \\
High P & 36 & 7 & 106 & 32 & 138 & 111 & 108 \\
High P+N & 45 & 9 & 131 & 36 & 167 & 135 & 138 \\
\end{tabular}

Table 3 Mean sheep and cattle numbers, lamb and cattle production (kg live weight/ha) and economic net margin (\$/ha) per farmlet (1999). Long term net margins for High P farmlets shown in brackets.

\begin{tabular}{lccccccc}
\hline & $\begin{array}{c}\text { Ewe } \\
\text { numbers }\end{array}$ & $\begin{array}{c}\text { Cattle } \\
\text { numbers }\end{array}$ & $\begin{array}{c}\text { Lamb } \\
\text { wt }\end{array}$ & $\begin{array}{c}\text { Cattle } \\
\text { wt gain }\end{array}$ & $\begin{array}{c}\text { Total } \\
\text { live wt }\end{array}$ & $\begin{array}{c}\text { Relative } \\
\text { live wt(\%) }\end{array}$ & $\begin{array}{c}\text { Net } \\
\text { margin }\end{array}$ \\
\hline Low P & 84 & 5 & 208 & 9 & 217 & 100 & 215 \\
Low P+N & 102 & 6 & 242 & 19 & 261 & 120 & 211 \\
High P & 98 & 6 & 258 & 8 & 266 & 123 & 225 \\
High P+N & 102 & 6 & 249 & 7 & 256 & 118 & $(245)$ \\
& & & & & & & 177 \\
\hline
\end{tabular}

Table 4 Mean sheep and cattle numbers, lamb and cattle production ( $\mathrm{kg}$ live weight/ha) and economic net margin (\$/ha) per farmlet (2000-2002). Long term net margins for High $\mathrm{P}$ farmlets shown in brackets.

\begin{tabular}{|c|c|c|c|c|c|c|c|}
\hline & $\begin{array}{c}\text { Ewe } \\
\text { numbers }\end{array}$ & $\begin{array}{c}\text { Cattle* }^{\star} \\
\text { numbers }\end{array}$ & $\begin{array}{c}\text { Lamb } \\
\text { wt }\end{array}$ & $\begin{array}{c}\text { Cattle } \\
\text { wt gain** }\end{array}$ & $\begin{array}{l}\text { Total } \\
\text { live wt }\end{array}$ & $\begin{array}{l}\text { Relative } \\
\text { live wt(\%) }\end{array}$ & $\begin{array}{c}\text { Net } \\
\text { margin }\end{array}$ \\
\hline Mod P & 88 & 11 & 157 & 31 & 187 & 100 & 188 \\
\hline Mod $\mathrm{P}+\mathrm{N}$ & 108 & 11 & 201 & 41 & 242 & 129 & 229 \\
\hline High P & 93 & 12 & 188 & 45 & 233 & 124 & $\begin{array}{c}180 \\
(200)\end{array}$ \\
\hline High $\mathrm{P}+\mathrm{N}$ & 111 & 12 & 220 & 41 & 261 & 139 & $\begin{array}{l}239 \\
(259)\end{array}$ \\
\hline
\end{tabular}

${ }^{\star}$ No cattle in 2000.

**Weight gains are means of 2001 and 2002 only when cattle grazed in late spring-summer only.

still relatively low on the High $\mathrm{P}+\mathrm{N}$ farmlet.

It was evident that whereas the additional animal production in the Low $\mathrm{P}+\mathrm{N}$ and High $\mathrm{P}$ farmlets largely compensated for the extra expenditure on fertiliser and stock, compared with the Low $\mathrm{P}$ farmlet, that animal production in the High $\mathrm{P}+\mathrm{N}$ farmlet was insufficient to compensate for the costs of both capital $\mathrm{P}$ and $\mathrm{N}$ fertiliser.

However there was inadequate control of pasture in spring each year on all of each farmlet which probably restricted lamb and cattle growth. A major reason for this was that each farmlet was stocked at the prescribed sheep:cattle ratio in autumn and while pasture control was readily achieved through winter, the faster pasture growth rates in spring, especially on the farmlets receiving extra fertiliser, were unable to be controlled by the cattle on the trial. 
The second significant period was in 1998 when there was a major drought. Rainfall totalled $105 \mathrm{~mm}$ in summer (December to February) followed by only $32 \mathrm{~mm}$ in March and April. Fertiliser $\mathrm{N}$ application was delayed until mid-winter because of low pasture cover, and ewesonly were placed on the trial in early May at lower numbers than in the 1995-1997 period. Cattle were on the trial at a ratio nearer 50:50 but only from 30 September to 9 November 1998 i.e. little more than a month.

In 1988 there were economic benefits to $\mathrm{N}$ fertiliser at both the Low P level, and at the long term High P level, but not to $\mathrm{P}$ fertiliser itself (Table 2). This was due to both better than average winter pasture responses to $\mathrm{N}$ fertiliser application (data not shown), and the use of ewes only, rather than ewes plus cattle, during winter, which provided proportionately higher lamb numbers. The return from the extra lambs was more profitable than if cattle had been carried through winter.

This stocking policy was continued in 1999, the third phase of Trial 1. As in 1998, and also because of dry spring weather, cattle were on the trial for a brief period only during spring and contributed little to the total animal productivity for the year (Table 3 ). The main outcome from this phase of the trial was that the higher ewe numbers on all farmlets, and the associated higher lamb production, including higher lambing percentages (130$145 \%$ ), were directly responsible for higher net margins on all farmlets than in previous years.

The economic returns from the Low $\mathrm{P}$, Low $\mathrm{P}+\mathrm{N}$ and High $\mathrm{P}$ farmlets were similar, being marginally higher from the High $\mathrm{P}$ farmlet, and especially in the long term scenario. Again the High $\mathrm{P}+\mathrm{N}$ farmlet had the lowest economic net margin.

In all of the above three phases of Trial 1, animal productivity was marginally higher from the Low $\mathrm{P}+\mathrm{N}$ farmlet than from the High $\mathrm{P}+\mathrm{N}$ farmlet, despite the additional $P$ fertiliser applied to the latter. This does not reflect the average pasture productivity measured from easy and steep sloping sites within each farmlet (Gillingham 1998), and may be related to other withinfarmlet differences, although the topographic composition of the two farmlets were similar.

\section{Trial 2}

In Trial 2 animal production from the High P farmlet averaged $24 \%$ more than from the Moderate $P$ farmlet (Table 4). The differential $\mathrm{N}$ fertiliser policy in the Moderate $\mathrm{P}+\mathrm{N}$ farmlet gave $29 \%$ higher animal productivity and $15 \%$ higher relative productivity at the High soil P level (i.e. High P cf. High P+N).

The farmlets receiving $\mathrm{N}$ fertiliser distinctly outproduced and economically out-performed the others. The lowest net margin was from the High P farmlet, whereas the highest production and net margin was from the High $\mathrm{P}+\mathrm{N}$ farmlet. The average lamb production for the three years from 2000-2002 was relatively low, as a result of a significant number of lamb deaths in a storm during lambing in 2002. A further factor was the relatively dry weather conditions in early spring of each year (i.e. only 32-57 mm rainfall in either August or September of each year). Ewes and lambs were therefore able to cope with pasture growth for all of spring 2000 (i.e no cattle were placed on the trial in 2000) and for most of the spring period in 2001 and 2002. Cattle were carried through into summer in these years only because of wetter than average conditions and associated continued pasture growth. This provided some compensation for the dry spring conditions.

\section{Discussion}

One of the main lessons from the two trials was that increased fertiliser application and animal production does not automatically result in increased economic returns. The first phase (1995-1997) of Trial 1 illustrated that a stocking policy which was based on winter pasture production, but did not allow enough flexibility to adequately utilise spring pasture growth, resulted in suboptimal lamb and cattle production, and limited economic benefits from the fertiliser applied.

The drought of 1998 forced a rethink of the stock policy and illustrated that if ewes only were stocked to potential through winter, and cattle introduced as necessary in the spring, then more complete pasture utilisation, and increased economic returns could be achieved. A system with flexible stock trading opportunities would offer the same potential. A significant additional factor in the results from 1998 was the very good pasture responses to $\mathrm{N}$ fertiliser achieved following the autumn drought. Although able to be measured in only one year, the effectiveness of $\mathrm{N}$ fertiliser applied following a drought, suggested that it was economically worthwhile.

In 1999 the same winter stocking policy was continued as adopted in 1998. However the relative animal production responses to $\mathrm{N}$ fertiliser were lower (Table 3) than in 1998 (Table 2), and insufficient to compensate for the additional costs ( $\$ 33 / \mathrm{ha})$, with the result that the economic net margins in the plus- $\mathrm{N}$ farmlets were lower than those from the Low P farmlet, but still higher than in 1998. For the High P farmlet the charge on the capital P fertiliser was less (\$20/ha) and showed a better economic return at a similar level of animal production. In the long term this farmlet showed the highest net margin.

The simulation exercise by Gillingham et al. (2003b) also found that the best economic returns from $\mathrm{N}$ fertiliser application were obtained when lamb production could be significantly increased, especially by increasing 
lambing percentages.

An interesting and obvious feature of the grazing management in spring 1999 was that the High P and High $\mathrm{P}+\mathrm{N}$ farmlets, which had the highest total stock numbers, including lambs, were the first farmlets to become short of pasture, and were destocked in early November, as soil moisture levels and pasture growth rates declined. The Low $\mathrm{P}$ and Low $\mathrm{P}+\mathrm{N}$ farmlets were not destocked until 3 weeks later. This indicated that the higher soil P fertility of the High P farmlets did not have any significant effect in prolonging pasture growth during the onset of dry conditions.

The trial protocol required all farmlets to be stocked at the same time in autumn once pasture cover levels of about $1500 \mathrm{~kg} \mathrm{DM} /$ ha were present. In the lead up period all farmlets were grazed to maintain pasture in a tidy condition. This may have marginally penalised the High $\mathrm{P}$ farmlets more than the Low P farmlets in the amounts of pasture that would have otherwise been present at the start date, and in the number of ewes that could be carried through the winter on those farmlets.

The differential fertiliser application programme adopted in Trial 2 for the Moderate $\mathrm{P}+\mathrm{N}$ and High $\mathrm{P}+\mathrm{N}$ farmlets, combined with the policy of maximising ewe numbers in winter, resulted in the highest economic returns of the total trial period.

A major advantage of the differential fertiliser application approach is that the appropriate $\mathrm{N}$ or $\mathrm{P}$ fertiliser is used on areas that will provide the most efficient responses from that type of fertiliser. It has therefore the advantage that the costs of applying both fertiliser types to the whole farmlet area are reduced, and is reflected in better economic returns, especially where high soil P levels are generated.

The use of costs and prices from 1997 for all analyses allowed year by year comparisons of the effects of management changes to be made. However, because of variations in pasture growth conditions from year to year the comparisons between farmlets within any one year are the most relevant. For comparison, if actual prices and costs had been used in the economic analysis of the results from 2000-2002, as reported by Gillingham et al. (2003b), the net margins would have been almost double those in Table 4 (i.e. $\$ 365, \$ 413, \$ 394$ and $\$ 435 /$ ha for the Moderate P, Moderate $\mathrm{P}+\mathrm{N}$, High $\mathrm{P}$ and High $\mathrm{P}+\mathrm{N}$ farmlets respectively). The differences in economic returns between farmlets was however less than double, reflecting the relatively greater increase in farm costs than prices over the intervening period since 1997.

\section{Conclusions}

There are a number of lessons that have been learnt from these trials. The first is that in such a climate as occurs on the east coast of the North Island there is no such thing as a normal year, or even a normal season. Winter rainfall is reasonably reliable but dry conditions can occur any time from early spring onwards, although in the 19952002 period a dry spring was usually followed by a wetter than average summer. Similarly, reliable autumn rainfall may occur as early as March or as late as late May. In such a climate it is of utmost importance to maximise pasture growth during the reliably wet winter period, especially on slopes that dry quickly once rain ceases. This is best achieved with $\mathrm{N}$ fertiliser.

The second lesson, that is not new, but reinforced by results from Trial 1 , is that pasture must be fully used during the period of active pasture growth if it is to be economically worthwhile. A third lesson is that the most profitable stock class should be used to do this. In these trials it was ewes producing lambs. A flexible stock trading policy could achieve the same results. Because spring rainfall is unreliable and pasture growth rates may slow or cease by mid-spring, land areas that are the most highly stocked will become short of pasture earliest, regardless of soil fertility level. Management must have the capability to deal with this by having alternative grazing available.

The final point is that differential fertiliser application and associated more intensive management will bring increased economic returns but the best combination will vary from property to property and farmer to farmer.

\section{ACKNOWLEDGEMENTS}

This research was primarily funded by the NZ Foundation for Research, Science and Technology, with valuable additional funding from Ravensdown Fertiliser, Petrochem and FertResearch. Technical assistance was provided by Alister Holman and Stuart MacMillan.

\section{REFERENCES}

Ball, P.R.; Field, T.R.O. 1982. Nitrogen on hill country. pp. 45-64. In: Nitrogen Fertilisers in New Zealand Agriculture. Ed. Lynch, P.B. New Zealand Institute of Agricultural Science.

Gillingham, A.G.; Gray, M.H.;; Smith, D. 1998. Pasture responses to phosphorus and nitrogen fertilisers on dry hill country. Proceedings of the New Zealand Grassland Association 60: 135-140.

Gillingham, A.G.; Maber, J.D.; Morton, J.; Tuohy, M. 1999. Precise fertiliser application on hill country. Proceedings of the New Zealand Grassland Association 61: 221-226.

Gillingham, A.G.; Morton, J.D.; Gray, M.H. 2003a. The role of differential fertiliser application in sustainable management of hill pastures. Proceedings of the New Zealand Grassland Association 65: 253-257.

Gillingham, A.G.; Sheath, G.W.; Gray, M.H.; Webby, R.W. 2003b. Management and fertiliser options for 
increased pasture productivity in dryland hill systems. Legumes for dryland pastures. Grassland Research and Practice Series 11: 43-49.

Lambert, M.G.;Clark, D.A. 1986. Effects of late autumn nitrogen application on hill country pastures and sheep production. Proceedings of the New Zealand
Grassland Association 47: 211-215.

Lambert, M.G.; Mackay, A.D.; Devantier, B. P.; McDougall, D.B.; Barker, D.J.; Park-Ng, Z.A. 2003.

Redefining the production potential of hill pastures using nitrogen fertiliser. Proceedings of the New Zealand Grassland Association 65: 35-40. 